\title{
Comparison of palonosetron and ondansetron to prevent postoperative nausea and vomiting in women using intravenous patient-controlled analgesia
}

Received April 23, 2019

Revised 1st, June 29, 2019

2nd, September 2, 2019

3rd, September 3, 2019

Accepted September 3, 2019

\section{Corresponding author}

Soon Im Kim, M.D., Ph.D.

Department of Anesthesiology and

Pain Medicine, Soonchunhyang

University Seoul Hospital, 59

Daesagwan-ro, Yongsan-gu, Seoul

04401, Korea

Tel: 82-2-709-9302

Fax: 82-2-790-0394

E-mail: soonnim@schmc.ac.kr

\section{ORCID}

https://orcid.org/0000-0001-8884-4096

\section{Jae Hwa Yoo', In Suk Jeon², Ji Won Chung', Jae Hoon Ryoo', Gyu Wan You', and Soon Im Kim ${ }^{1}$}

Department of Anesthesiology and Pain Medicine, 'Soonchunhyang University Seoul Hospital, Seoul, 'Soonchunhyang University Gumi Hospital, Gumi, Korea

\begin{abstract}
Background: We compared the effects of palonosetron with ondansetron for preventing postoperative nausea and vomiting (PONV) during the first $24 \mathrm{~h}$ after surgery in women receiving intravenous patient-controlled analgesia (IV-PCA) with fentanyl for pain control.

Methods: In this prospective, randomized, double-blinded study, 204 healthy patients who were undergoing elective surgery with general anesthesia were enrolled. In the palonosetron group ( $n=102$ ), $0.075 \mathrm{mg}$ bolus was given intravenously (i.v.) $30 \mathrm{~min}$ before the end of surgery and $8 \mathrm{ml}$ saline was added to the IV-PCA. In the ondansetron group ( $n=102$ ), $8 \mathrm{mg}$ bolus i.v. was given $30 \mathrm{~min}$ before the end of surgery and $16 \mathrm{mg}$ of ondansetron was added to the IV-PCA. The incidence of PONV, severity of nausea, and use of rescue anti-emetics were evaluated 6 and $24 \mathrm{~h}$ after the operation.
\end{abstract}

Results: The incidences of nausea (55.6\%) and vomiting (14.1\%) in the palonosetron group did not differ from those (58.3 and 19.8\%) in the ondansetron group during the first $24 \mathrm{~h}$ after surgery $(P>0.05)$. No significant differences were observed in the severity of nausea and use of rescue anti-emetics between the two groups $(P>0.05)$.

Conclusions: The effects of palonosetron in preventing PONV were not different from those of ondansetron during the first $24 \mathrm{~h}$ postoperatively in women receiving IV-PCA with fentanyl.

Keywords: Ondansetron; Palonosetron; Postoperative nausea and vomiting.

\section{INTRODUCTION}

Postoperative nausea and vomiting (PONV), also known as the "big little problem," is a common complication after surgery and general anesthesia. It is an unpleasant and distressing experience that can delay recovery and discharge, resulting in reduced patient satisfaction [1].

5-Hydroxytryptamine $3\left(5-\mathrm{HT}_{3}\right)$ receptor antagonists are widely used drugs to treat PONV due to their good efficacy and safety profiles [2]. Ondansetron is the first drug used to treat patients suffering from chemotherapy-induced nausea and vomiting (CINV) and PONV among $5-\mathrm{HT}_{3}$ receptor antagonists and has been the most studied, so its effectiveness and efficacy in preventing PONV have been well established. Ondansetron is the gold standard compared to other antiemetics [2].

Palonosetron is the most recently introduced secondgeneration $5-\mathrm{HT}_{3}$ receptor antagonist. It has a longer half-

This is an Open Access article distributed under the terms of the Creative Commons Attribution Non-Commercial License (http://creativecommons.org/licenses/by-nc/4.0) which permits unrestricted non-commercial use, distribution, and reproduction in any medium, provided the original work is properly cited.

Copyright (c) the Korean Society of Anesthesiologists, 2020 
life ( $>40 \mathrm{~h}$ ) and stronger receptor affinity than the older firstgeneration $5-\mathrm{HT}_{3}$ receptor antagonists and displays allosteric binding with positive cooperativity, which effectively extends the inhibitory receptor function [3]. Palonosetron has superior prophylactic effects than ondansetron in both acute and delayed CINV [4], and is effective for preventing PONV compared to placebo for $72 \mathrm{~h}$ postoperatively [5].

Ondansetron, dolasetron, granisetron, tropisetron, and ramosetron, which are older 5- $\mathrm{HT}_{3}$ receptor antagonists, have similar clinical efficacies for preventing PONV [2,6,7]. It is expected that the second-generation $5-\mathrm{HT}_{3}$ receptor antagonist palonosetron might be an exception.

Some studies have compared the efficacy of palonosetron to prevent PONV with the older 5- $\mathrm{HT}_{3}$ receptor antagonists. However, most studies that have compared the efficacy of palonosetron to prevent PONV with ondansetron have used single preoperative drug administration timing and have not considered the relatively short half-life of ondansetron [8-15]. Considering the relatively short half-life of ondansetron, studies utilizing a continuous infusion of ondansetron are rare, and this issue remains controversial. In one study, palonosetron was significantly superior for decreasing the incidence of PONV compared to ondansetron [16], whereas in another study the prophylactic effects of both agents were similar during the first $24 \mathrm{~h}$ after surgery [17].

Therefore, this study compared the efficacy of palonosetron in preventing PONV with that of ondansetron using continuous infusion, during the first $24 \mathrm{~h}$ postoperatively in women receiving intravenous patient-controlled analgesia (IV-PCA) with fentanyl.

\section{MATERIALS AND METHODS}

This prospective, randomized, double-blinded study was approved by the Institutional Review Board of our hospital (no. 2013-021) before study commencement.

After receiving written informed consent, we enrolled 204 healthy female patients, aged 20-70 years with American Society of Anesthesiologists physical status I or II, who were scheduled for elective surgery under general anesthesia and wanted to receive IV-PCA for postoperative pain relief. The exclusion criteria were pregnancy; body mass index $>30 \mathrm{~kg} / \mathrm{m}^{2}$; nausea or vomiting within $24 \mathrm{~h}$ before the operation; administration of anti-emetics or steroids or psychoactive medications within
$24 \mathrm{~h}$ before the operation; and impaired communication.

Patients were randomly allocated to one of two groups according to a computer-generated random number table using block sizes of 2,4 , and 8 . In the palonosetron group (n = 102), $0.075 \mathrm{mg}$ of palonosetron was administered intravenously (i.v.) $30 \mathrm{~min}$ before the end of the operation, and $8 \mathrm{ml}$ normal saline was added to the IV-PCA. In the ondansetron group ( $\mathrm{n}=102), 8 \mathrm{mg}$ of ondansetron was administered i.v. $30 \mathrm{~min}$ before the end of the operation, and $16 \mathrm{mg}$ of ondansetron was added to the IV-PCA. The study drugs were contained in identical syringes and the IV-PCA units were prepared by nurses not involved in the study.

A standardized anesthesia regimen was followed. All patients received 3-5 mg of midazolam intramuscularly as premedication $30 \mathrm{~min}$ before the operation. General anesthesia was induced with propofol at $2 \mathrm{mg} / \mathrm{kg}$ and a continuous remifentanil infusion. Rocuronium $(0.6 \mathrm{mg} / \mathrm{kg})$ was administered to facilitate endotracheal intubation. Anesthesia was maintained with desflurane or sevoflurane and nitrous oxide in oxygen (50\%) with continuous remifentanil infusion. The inhaled anesthetics were adjusted to maintain an adequate anesthetic depth (bispectral index 40-60). At the end of the surgery, residual neuromuscular block was reversed with pyridostigmine and glycopyrrolate. The patients were given fentanyl in an IV-PCA unit beginning at the end of the operation. The PCA formulation consisted of $1,500 \mu \mathrm{g}$ of fentanyl diluted to $100 \mathrm{ml}$ in normal saline; the basal rate was set to 1 $\mathrm{ml} / \mathrm{h}$, with a bolus of $1 \mathrm{ml}$ and a lock-out time of $5 \mathrm{~min}$. After surgery, the patients were observed in the post-anesthetic care unit for $1 \mathrm{~h}$ and then transferred to the ward.

The incidence of nausea and vomiting, severity of nausea, and use of rescue anti-emetics were evaluated at 1, 6, and 24 $\mathrm{h}$ after the operation by an investigator who was blinded to the group assignments. An episode of vomiting was defined as vomiting (expulsion of stomach contents) or retching (an involuntary attempt to vomit but producing no stomach contents). Nausea severity was assessed using a 4-point verbal rating scale (none, mild, moderate and severe). Patients were asked to rate their maximal degree of nausea during the assessment interval. Rescue medication for PONV (10 mg of metoclopramide as an initial rescue drug and $0.3 \mathrm{mg}$ of ramosetron as a second rescue drug) was administered upon the patient's request or complaint of moderate to severe nausea or vomiting. Additional analgesic medications were 
allowed at the discretion of the surgeon for inadequate pain control despite sufficient use of IV-PCA. Pain intensity was not assessed.

Adverse events were evaluated and recorded during the entire observation period. Patient satisfaction with the anesthetic experience was evaluated on a 3-point scale (satisfied, neutral, and dissatisfied) $24 \mathrm{~h}$ postoperatively.

The primary outcome was the incidence of PONV during the first $24 \mathrm{~h}$ after the operation. The secondary outcomes were nausea severity, use of rescue anti-emetics during the first $24 \mathrm{~h}$ after the operation, all adverse effects, and patient satisfaction.

Sample size was calculated based on the results of a study that compared the anti-emetic effects of ondansetron and palonosetron on PONV (62 vs. $42 \%$ ) in highly susceptible patients [16]. The sample size was estimated to be 97 patients per group for a two-sided test using $\alpha=0.05$ and $\beta=0.2$. We enrolled 102 patients per group to allow for possible patient dropout (5\%).

Statistical analyses were performed using SPSS for Windows (version 14; SPSS Inc., USA). Student's $t$-test was used to compare continuous variables between the groups. Categorical variables were analyzed using the $\chi^{2}$ test or Fisher's exact test, as appropriate. A P value $<0.05$ was considered statistically significant. Data are presented as means \pm standard deviations, numbers, or percentages.

\section{RESULTS}

Among the 204 patients enrolled in this study, 9 withdrew due to a protocol violation. Data obtained from the remaining 195 patients were analyzed (99 patients in the palonosetron group and 96 patients in the ondansetron group) (Fig. 1).

No significant differences in age, body weight, previous PONV history, motion sickness, smoking status, duration of surgery and anesthesia, or type of surgery were observed between the two groups (Table 1).

The incidence of nausea ( $55.6 \%$ vs. $58.3 \%$, palonosetron group vs. ondansetron group, respectively) and vomiting

Table 1. Patient Characteristics

\begin{tabular}{lccc}
\hline \multicolumn{1}{c}{ Variable } & $\begin{array}{c}\text { Palonosetron } \\
(\mathrm{n}=99)\end{array}$ & $\begin{array}{c}\text { Ondansetron } \\
(\mathrm{n}=96)\end{array}$ & P value \\
\hline Age (yr) & $52 \pm 11.0$ & $50 \pm 11.8$ & 0.159 \\
Body weight (kg) & $60 \pm 8.5$ & $61 \pm 8.8$ & 0.690 \\
Duration of operation (min) & $94 \pm 54.4$ & $97 \pm 60.1$ & 0.711 \\
Duration of Anesthesia (min) & $135 \pm 60.2$ & $138 \pm 65.2$ & 0.749 \\
Previous PONV history & 7 & 8 & 0.804 \\
Motion sickness history & 24 & 36 & 0.062 \\
Non-smoking status & 92 & 91 & 0.733 \\
Types of surgery & & & 0.945 \\
$\quad$ Orthopedic surgery & 63 & 59 & \\
$\quad$ Gynecological surgery & 21 & 20 & \\
Head and neck surgery & 10 & 10 & \\
Laparoscopic surgery & 5 & 7 &
\end{tabular}

Data are presented as mean \pm SD or number of patient. PONV: postoperative nausea and vomiting.

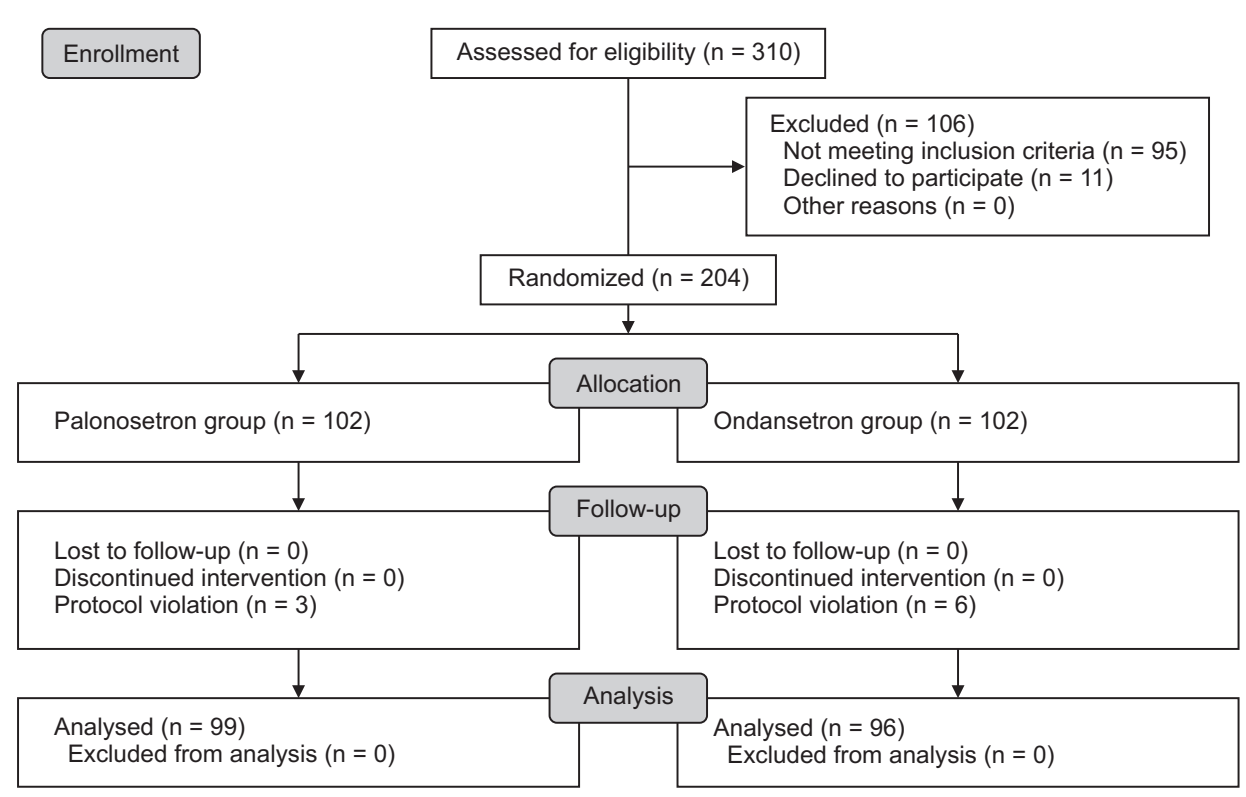

Fig. 1. CONSORT diagram. CONSORT: consolidated standards of reporting trials. 
( $14.1 \%$ vs. $19.8 \%$, palonosetron group vs. ondansetron group, respectively), and the use of rescue anti-emetics (29.3\% vs. $29.2 \%$, palonosetron group vs. ondansetron group, respectively) in the first $24 \mathrm{~h}$ after the operation did not differ between the groups $(\mathrm{P}>0.05)$ (Table 2).

The severity of nausea in the first $24 \mathrm{~h}$ after the operation did not differ between the groups $(\mathrm{P}>0.05)$ (Table 3).

Patient satisfaction and adverse effects also did not differ between the groups (both $\mathrm{P}>0.05$ ) (Table 4).

\section{DISCUSSION}

The efficacy of palonosetron in preventing PONV during the first $24 \mathrm{~h}$ postoperatively was not different from that of ondansetron in women receiving IV-PCA with fentanyl for postoperative pain control.

There are many mediators and diverse pathways in PONV, and their mechanisms are complex and unclear [18]. Known risk factors for PONV include female sex, younger age, opioid use, non-smoking status, history of motion sickness or PONV, long anesthesia duration, and use of inhalation anesthetics [2]. In this study, the risk factors did not differ between the two groups, as both groups had two or more risk factors for PONV.

Palonosetron is a second-generation $5-\mathrm{HT}_{3}$ receptor an-

Table 2. Incidences of Nausea and Vomiting, and Use of Rescue Antiemetics during the First 24 Hours after Operation

\begin{tabular}{lccc}
\hline \multicolumn{1}{c}{ Variable } & $\begin{array}{c}\text { Palonosetron } \\
(\mathrm{n}=99)\end{array}$ & $\begin{array}{c}\text { Ondansetron } \\
(\mathrm{n}=96)\end{array}$ & P value \\
\hline 0-6 h & & & \\
$\quad$ Nausea & $40(40.4)$ & $41(42.7)$ & 0.744 \\
Vomiting & $12(12.1)$ & $8(8.3)$ & 0.383 \\
PONV & $40(40.4)$ & $41(42.7)$ & 0.744 \\
Rescue anti-emetics & $18(18.2)$ & $17(17.7)$ & 0.931 \\
6-24 h & & & \\
Nausea & $39(39.4)$ & $43(44.8)$ & 0.445 \\
Vomiting & $6(6.1)$ & $13(13.5)$ & 0.078 \\
PONV & $40(40.4)$ & $43(44.8)$ & 0.536 \\
$\quad$ Rescue anti-emetics & $16(16.2)$ & $19(19.8)$ & 0.509 \\
0-24 h & & & \\
Nausea & $55(55.6)$ & $56(58.3)$ & 0.695 \\
Vomiting & $14(14.1)$ & $19(19.8)$ & 0.293 \\
PONV & $55(55.6)$ & $56(58.3)$ & 0.695 \\
Rescue anti-emetics & $29(29.3)$ & $28(29.2)$ & 0.985 \\
\hline
\end{tabular}

Data are presented as number of patients (\%). PONV: postoperative nausea and vomiting. tagonist with different properties compared to older $5-\mathrm{HT}_{3}$ receptor antagonists. First, the chemical structure differs, as palonosetron has a fused tricyclic ring system unlike the firstgeneration drugs that have a 3-substituted indole structure resembling serotonin [3]. Second, the affinity for the $5-\mathrm{HT}_{3}$ receptor is much higher than that of first-generation drugs $(\mathrm{pKi}$ $=10.45)$ and plasma half-life is $>40 \mathrm{~h}[19,20]$. Third, palonosetron displays allosteric binding with positive cooperativity and triggers receptor internalization resulting in long-term inhibition of receptor function, whereas the older $5-\mathrm{HT}_{3}$ receptor antagonists selectively antagonize serotonin through competitive bimolecular binding and occupancy at the $5-\mathrm{HT}_{3}$ receptor. This unique binding activity makes palonosetron work effectively. In addition, its long duration of action comes not only from its long half-life but also from the long-term inhibition of receptor function by inducing receptor internalization [3].

Table 3. Severity of Nausea during the First 24 Hours after Operation

\begin{tabular}{lccc}
\hline Severity of nausea & $\begin{array}{c}\text { Palonosetron } \\
(\mathrm{n}=99)\end{array}$ & $\begin{array}{c}\text { Ondansetron } \\
(\mathrm{n}=96)\end{array}$ & P value \\
\hline 0-6 h & & & \\
None & $59(59.6)$ & $55(57.3)$ & 0.511 \\
Mild & $7(7.1)$ & $13(13.5)$ & \\
Moderate & $12(12.1)$ & $10(10.4)$ & \\
Severe & $21(21.2)$ & $18(18.8)$ & \\
6-24 h & & & \\
None & $60(60.6)$ & $53(55.2)$ & 0.541 \\
Mild & $13(13.1)$ & $18(18.8)$ & \\
Moderate & $9(9.1)$ & $12(12.5)$ & \\
Severe & $17(17.2)$ & $13(13.5)$ & \\
0-24 h & & & \\
None & $44(44.4)$ & $40(41.7)$ & 0.543 \\
Mild & $10(10.1)$ & $19(19.8)$ & \\
Moderate & $13(13.1)$ & $14(14.6)$ & \\
Severe & $32(32.3)$ & $23(24.0)$ & \\
\hline
\end{tabular}

Data are presented as number of patients (\%).

Table 4. Adverse Side Effects and Patients' Satisfaction

\begin{tabular}{lccc}
\hline \multicolumn{1}{c}{ Variable } & $\begin{array}{c}\text { Palonosetron } \\
(\mathrm{n}=99)\end{array}$ & $\begin{array}{c}\text { Ondansetron } \\
(\mathrm{n}=96)\end{array}$ & P value \\
\hline Adverse effects & & & \\
$\quad$ Dizziness & $22(22.2)$ & $33(34.4)$ & 0.059 \\
Headache & $21(21.2)$ & $25(26.0)$ & 0.427 \\
Satisfaction & & & \\
Satisfied & $77(77.8)$ & $70(72.9)$ & 0.673 \\
Neutral & $18(18.2)$ & $20(20.8)$ & \\
Dissatisfied & $4(4.0)$ & $6(6.3)$ & \\
\hline
\end{tabular}

Data are presented as number of patients (\%). 
Superior results have been reported for palonosetron in studies that compared the preventive effects of acute and delayed CINV with those of ondansetron or dolasetron $[4,21]$. Palonosetron is the only $5-\mathrm{HT}_{3}$ receptor antagonist used for the prevention of both acute and delayed CINV [22].

Two pivotal placebo-controlled trials were conducted to evaluate the dose-response efficacy and safety of three different doses of palonosetron for preventing PONV within 72 $\mathrm{h}$ after surgery. Those studies demonstrated that $0.075 \mathrm{mg}$ of palonosetron i.v. was the most effective and well tolerated, and had the best prophylactic effect mainly in the first $24 \mathrm{~h}$ after surgery, and it was subsequently approved by the US Food and Drug Administration for preventing PONV for up to $24 \mathrm{~h}$ after surgery [5,23].

Ondansetron has largely been studied for its effectiveness and efficacy compared to other classes of anti-emetics and has similar efficacy to already proven anti-emetics, such as droperidol and dexamethasone [24,25]. In addition, it has become the gold standard in clinical efficacy studies with other 5- $\mathrm{HT}_{3}$ receptor antagonists such as dolasetron, granisetron, tropisetron, and ramosetron, which have been introduced since ondansetron.

Consequently, the older $5-\mathrm{HT}_{3}$ receptor antagonists are considered equally effective when given at equipotent doses, and they are chosen according to their accessibility, ease of use, and economy in clinical practice $[2,6,7]$.

The recommended timing of drug administration is different between palonosetron and other $5-\mathrm{HT}_{3}$ receptor antagonists. Palonosetron is typically recommended to be given at the beginning of surgery, while other $5-\mathrm{HT}_{3}$ antagonists are recommended to be given at the end of surgery [2]. However, in most studies comparing the efficacy of palonosetron in preventing PONV with other $5-\mathrm{HT}_{3}$ receptor antagonists, including ondansetron, identical drug administration timing was used due to the blinding method. In many cases, preoperative single administration was selected [8-15]. In these studies, most authors reported superior efficacy of palonosetron in preventing PONV compared with ondansetron [8-15]. However, preoperative administration is advantageous for palonosetron, and it is possible that the decreased efficacy due to the relatively short half-life of ondansetron may have affected the incidence of PONV. Therefore, we administered the study drugs $30 \mathrm{~min}$ before the end of the operation and continuously infused ondansetron using PCA in the ondan- setron group.

In this study, because the equipotent doses of palonosetron and ondansetron were unknown, palonosetron was given at the recommended dose of $0.075 \mathrm{mg}$ to prevent PONV [5,23], and ondansetron was administered using the following regimen, which may be clinically effective $[16,17]$. We adopted 8 mg of ondansetron administered i.v. based on a systematic review showing that $8 \mathrm{mg}$ of ondansetron is more optimal than $4 \mathrm{mg}$ [24], and $16 \mathrm{mg}$ was added to the IV-PCA based on a study showing that adding ondansetron or ramosetron to fentanyl-based PCA is more effective than just a single-dose of ramosetron for preventing PONV during the first $48 \mathrm{~h}$ after surgery [26].

Among the studies comparing the efficacy of palonosetron with ondansetron in preventing PONV, two studies have added ondansetron to PCA. Kim et al. [17] compared the prophylactic effects of preoperative palonosetron $(0.075 \mathrm{mg}$, i.v.) with a regimen of preoperative ondansetron ( $8 \mathrm{mg}, \mathrm{i} . \mathrm{v}$. and $16 \mathrm{mg}$ added to PCA in women undergoing laparoscopic gynecological surgery using fentanyl IV-PCA for $72 \mathrm{~h}$ postoperatively, but they found no significant differences between the two groups in the incidence rates of PONV at any of the evaluation time points $(2,24,48$, and $72 \mathrm{~h})$, despite giving the bolus before inducing anesthesia. In particular, the incidence of PONV was $40 \%$ in the ondansetron group and $44 \%$ in the palonosetron group $24 \mathrm{~h}$ postoperatively, and palonosetron and ondansetron did not differ in their PONV-preventive effects during the first $24 \mathrm{~h}$ postoperatively. Moon et al. [16] compared the prophylactic effects of $0.075 \mathrm{mg}$ of palonosetron i.v. with the regimen of $8 \mathrm{mg}$ of ondansetron i.v. and 16 mg added to the PCA in women receiving a thyroidectomy using fentanyl-based IV-PCA. Palonosetron significantly reduced the incidence of PONV during the first $24 \mathrm{~h}$ postoperatively, compared to ondansetron (42 vs. $62 \%$, respectively).

In this study, the incidence of PONV was $55.6 \%$ in the palonosetron group and $58.3 \%$ in the ondansetron group at $24 \mathrm{~h}$ postoperatively. No significant differences in PONV preventive effects were observed. Our results are consistent with those of Kim et al. [17]. However, the incidence of PONV in our study was higher than that of Kim et al. [17], but similar to that in the ondansetron group of Moon et al. [16]. The relatively higher incidence of PONV in our study might be related with longer anesthetic time and various surgical types.

In addition, the relative risk reduction for PONV using 
$0.075 \mathrm{mg}$ of palonosetron is about $0.30[5,27]$ and that of $4 \mathrm{mg}$ of ondansetron for PONV is 0.26 [25], suggesting that the efficacy of palonosetron and ondansetron is similar. Likewise, we found that palonosetron was similar but not superior to ondansetron during the first $24 \mathrm{~h}$ postoperatively. Therefore, we presume that all $5-\mathrm{HT}_{3}$ receptor antagonists have equal efficacy during the acute period, even though they have different durations of action, because they all act on the same receptor, and the prophylactic efficacy of one anti-emetic that functions on one class of receptor is limited [28,29].

Although we found that the prophylactic efficacy of palonosetron for the first $24 \mathrm{~h}$ was comparable to that of ondansetron, palonosetron has many advantages that make it more promising and useful than ondansetron. Palonosetron has no QT prolongation issue in terms of safety [30]. It also has a longer duration of action that produces a prophylactic effect in delayed PONV, particularly post-discharge nausea and vomiting, which is a growing problem in outpatient anesthesia.

This study has several limitations. First, it was an active control comparison without a placebo group because of ethical problems inherent in trials using high-risk subjects. Second, equipotent doses of palonosetron and ondansetron were not used; rather, optimal doses were used. Additional studies are needed to determine the equipotent doses of these drugs to prevent PONV. Third, we used different injection methods; ondansetron was continuously infused using PCA, whereas palonosetron was injected once as a bolus because palonosetron has a longer half-life than ondansetron. This may have caused pharmacokinetic differences. In addition, the study drugs were administered $30 \mathrm{~min}$ before the end of the operation, rather than the optimal time for each drug, because it was a double-blind trial [2]. This might also have affected the conclusions of the study. Additional studies using optimal timing for each drug are needed. Fourth, pain intensity and additional analgesic medications were not assessed in this study because the use of additional analgesics at the discretion of the surgeon was determined to have a minor impact on the conclusions of the study. However, this may have affected the conclusions of the study.

In conclusion, the effects of palonosetron to prevent PONV were not significantly different from those of ondansetron in women receiving IV-PCA with fentanyl for the first $24 \mathrm{~h}$ postoperatively.

\section{CONFLICTS OF INTEREST}

No potential conflict of interest relevant to this article was reported.

\section{ORCID}

Jae Hwa Yoo, https://orcid.org/0000-0003-0675-0761

In Suk Jeon, https://orcid.org/0000-0001-7542-9643

Ji Won Chung, https://orcid.org/0000-0003-4573-9100

Jae Hoon Ryoo, https://orcid.org/0000-0001-8296-5743

Gyu Wan You, https://orcid.org/0000-0003-1373-6538

\section{REFERENCES}

1. Kovac AL. Update on the management of postoperative nausea and vomiting. Drugs 2013; 73: 1525-47.

2. Gan TJ, Diemunsch P, Habib AS, Kovac A, Kranke P, Meyer TA, et al. Consensus guidelines for the management of postoperative nausea and vomiting. Anesth Analg 2014; 118: 85-113.

3. Rojas C, Stathis M, Thomas AG, Massuda EB, Alt J, Zhang J, et al. Palonosetron exhibits unique molecular interactions with the 5-HT3 receptor. Anesth Analg 2008; 107: 469-78.

4. Gralla R, Lichinitser M, Van Der Vegt S, Sleeboom H, Mezger J, Peschel C, et al. Palonosetron improves prevention of chemotherapy-induced nausea and vomiting following moderately emetogenic chemotherapy: results of a double-blind randomized phase III trial comparing single doses of palonosetron with ondansetron. Ann Oncol 2003; 14: 1570-7.

5. Kovac AL, Eberhart L, Kotarski J, Clerici G, Apfel C. A randomized, double-blind study to evaluate the efficacy and safety of three different doses of palonosetron versus placebo in preventing postoperative nausea and vomiting over a 72-hour period. Anesth Analg 2008; 107: 439-44.

6. Ho KY, Gan TJ. Pharmacology, pharmacogenetics, and clinical efficacy of 5-hydroxytryptamine type 3 receptor antagonists for postoperative nausea and vomiting. Curr Opin Anaesthesiol 2006; 19: 606-11.

7. Kim SI, Kim SC, Baek YH, Ok SY, Kim SH. Comparison of ramosetron with ondansetron for prevention of postoperative nausea and vomiting in patients undergoing gynaecological surgery. $\mathrm{Br} \mathrm{J}$ Anaesth 2009; 103: 549-53.

8. AbdEl-Hamid AM, Othman MSK, Afifi EE. Palonosetron versus ondansetron for prevention of postoperative nausea and vomiting during middle ear surgery: a double-blind, randomized, comparative trial. Ain-Shams J Anesthesiol 2014; 7: 309-13. 
9. Bajwa SS, Bajwa SK, Kaur J, Sharma V, Singh A, Singh A, et al. Palonosetron: a novel approach to control postoperative nausea and vomiting in day care surgery. Saudi J Anaesth 2011; 5: 19-24.

10. Bhalla J, Baduni N, Bansal P. Comparison of palanosetron with ondansetron for postoperative nausea and vomiting in patients undergoing laparoscopic cholecystectomy under general anesthesia. J Minim Access Surg 2015; 11: 193-7.

11. Joshi H, Parmar P, Raval B. Comparison of ondansetron v/s palonosetron for prevention of post-operative nausea and vomiting in laparoscopic surgery. Res J Pharm Biol Chem Sci 2014; 5: 5463.

12. Kim SH, Hong JY, Kim WO, Kil HK, Karm MH, Hwang JH. Palonosetron has superior prophylactic antiemetic efficacy compared with ondansetron or ramosetron in high-risk patients undergoing laparoscopic surgery: a prospective, randomized, double-blinded study. Korean J Anesthesiol 2013; 64: 517-23.

13. Park SK, Cho EJ. A randomized, double-blind trial of palonosetron compared with ondansetron in preventing postoperative nausea and vomiting after gynaecological laparoscopic surgery. J Int Med Res 2011; 39: 399-407.

14. Shadangi BK, Agrawal J, Pandey R, Kumar A, Jain S, Mittal R, et al. A prospective, randomized, double-blind, comparative study of the efficacy of intravenous ondansetron and palonosetron for prevention of postoperative nausea and vomiting. Anaesth Pain Intensive Care 2013; 17: 55-8.

15. Sharma AN, Shankaranarayana P. Postoperative nausea and vomiting: palonosetron with dexamethasone vs. ondansetron with dexamethasone in laparoscopic hysterectomies. Oman Med J 2015; 30: 252-6.

16. Moon YE, Joo J, Kim JE, Lee Y. Anti-emetic effect of ondansetron and palonosetron in thyroidectomy: a prospective, randomized, double-blind study. Br J Anaesth 2012; 108: 417-22.

17. Kim YY, Moon SY, Song DU, Lee KH, Song JW, Kwon YE. Comparison of palonosetron with ondansetron in prevention of postoperative nausea and vomiting in patients receiving intravenous patient-controlled analgesia after gynecological laparoscopic surgery. Korean J Anesthesiol 2013; 64: 122-6.

18. Watcha MF, White PF. Postoperative nausea and vomiting. Its etiology, treatment, and prevention. Anesthesiology 1992; 77: 16284.

19. Wong EH, Clark R, Leung E, Loury D, Bonhaus DW, Jakeman L, et al. The interaction of RS 25259-197, a potent and selective antagonist, with 5-HT3 receptors, in vitro. Br J Pharmacol 1995;
114: 851-9.

20. Stoltz R, Cyong JC, Shah A, Parisi S. Pharmacokinetic and safety evaluation of palonosetron, a 5-hydroxytryptamine-3 receptor antagonist, in U.S. and Japanese healthy subjects. J Clin Pharmacol 2004; 44: 520-31.

21. Aapro MS, Grunberg SM, Manikhas GM, Olivares G, Suarez T, Tjulandin SA, et al. A phase III, double-blind, randomized trial of palonosetron compared with ondansetron in preventing chemotherapy-induced nausea and vomiting following highly emetogenic chemotherapy. Ann Oncol 2006; 17: 1441-9.

22. Siddiqui MA, Scott LJ. Palonosetron. Drugs 2004; 64: 1125-32; discussion 1133-4.

23. Candiotti KA, Kovac AL, Melson TI, Clerici G, Joo Gan T; Palonosetron 04-06 Study Group. A randomized, double-blind study to evaluate the efficacy and safety of three different doses of palonosetron versus placebo for preventing postoperative nausea and vomiting. Anesth Analg 2008; 107: 445-51.

24. Tramèr MR, Reynolds DJ, Moore RA, McQuay HJ. Efficacy, doseresponse, and safety of ondansetron in prevention of postoperative nausea and vomiting: a quantitative systematic review of randomized placebo-controlled trials. Anesthesiology 1997; 87: 1277-89.

25. Apfel CC, Korttila K, Abdalla M, Kerger H, Turan A, Vedder I, et al. A factorial trial of six interventions for the prevention of postoperative nausea and vomiting. N Engl J Med 2004; 350: 2441-51.

26. Choi DK, Chin JH, Lee EH, Lim OB, Chung CH, Ro YJ, et al. Prophylactic control of post-operative nausea and vomiting using ondansetron and ramosetron after cardiac surgery. Acta Anaesthesiol Scand 2010; 54: 962-9.

27. Chun HR, Jeon IS, Park SY, Lee SJ, Kang SH, Kim SI. Efficacy of palonosetron for the prevention of postoperative nausea and vomiting: a randomized, double-blinded, placebo-controlled trial. Br J Anaesth 2014; 112: 485-90.

28. Tramèr MR. A rational approach to the control of postoperative nausea and vomiting: evidence from systematic reviews. Part I. efficacy and harm of antiemetic interventions, and methodological issues. Acta Anaesthesiol Scand 2001; 45: 4-13.

29. Apfel CC, Roewer N, Korttila K. How to study postoperative nausea and vomiting. Acta Anaesthesiol Scand 2002; 46: 921-8.

30. Morganroth J, Flaharty KK, Parisi S, Moresino C. Effect of single doses of IV palonosetron, up to $2.25 \mathrm{mg}$, on the QTc interval duration: a double-blind, randomized, parallel group study in healthy volunteers. Support Care Cancer 2016; 24: 621-7. 